\title{
Evaluation of Performance Non-signal Intersection on Telekomunikasi Road Intersection - Terusan Buah Batu Road, Bandung - West Java
}

\author{
Asep Setiawan \\ Department of Civil Engineering, Faculty of Engineering, Widyatama University, Bandung, East Java, Indonesia
}

Copyright $\mathrm{C} 2019$ by authors, all rights reserved. Authors agree that this article remains permanently open access under the terms of the Creative Commons Attribution License 4.0 International License

\begin{abstract}
Evaluation of performance non-signal intersection on Telekomunikasi Road Intersection Terusan Buah Batu Road is carried out by considering the geometric conditions of the road, traffic volume, side barriers, and environmental conditions around the intersection. Primary data and secondary data were analyzed by referring to the Indonesian Road Capacity Manual Method (MKJI 1997). From the results of the study, it was found that on Wednesday at 15:20 - 16:20, the maximum capacity value of 9,326/hours exceeded the base capacity of type 324 crossing ( $\mathrm{Co}=3,200 \mathrm{pcu} /$ hour). The highest degree of saturation (DS) occurs on Monday at $6: 20-7: 20$, which is 0.86 . This means that the service level value is in class E $(0.85-1.00)$. Namely, unstable traffic flow, solid vehicles, stagnant traffic and intersection volume higher are than its capacity, so that crossing conditions require handling. From the data above, it is known that the Telekomunikasi Road intersection Terusan Buah Batu Road is not feasible to accommodate traffic flows and it needs to be handled by making stop lines, road signs as vehicle lane separators and warning signs, danger signs or by installing traffic signal lights.
\end{abstract}

Keywords Non-signalized Intersection, Capacity, Degree of Saturation, Delay

\section{Introduction}

The Telekomunikasi Road Intersection - Buah Batu Road is a type of non-signalized intersection. The pattern of regulating traffic at this intersection is not optimal; this can be seen from the quite heavy traffic flow and congestion, especially during rush hour in the morning, afternoon, and in the afternoon.

By taking into account the geometric conditions of the road, the volume of traffic flow, side barriers and intersection environment, which is a commercial area, and then try to evaluate the performance of the three-arm unsignalized intersection of Telekomunikasi Road - Buah Batu Road, Bandung Regency.

The purpose of this study was to determine the traffic behavior at an unsignalized intersection on Telekomunikasi Road - Terusan Buah Batu Road using the Indonesian Road Capacity Manual (MKJI) 1997. The results of this study are expected to be a reference and input for related agencies that are directly or indirectly related directly in traffic to make new planning and steps in accordance with community needs, so that it can be applied in reducing congestion on existing road capacity.

\section{Literature Review}

\subsection{Non-signal Intersection}

Non-signalized intersections with road rights arrangements (priority from the left) are generally used in urban settlements and inland areas for intersections between local roads and low traffic flows. For intersections with different classes and/ or functions of roads, traffic on minor roads must be set with a "yield" or "stop" sign.

The 1997 Indonesian Road Capacity Manual (MKJI) distinguishes intersections from signalized intersections (traffic signals) and non-signal intersections (non-traffic signals). Non-signalized intersections are controlled by the basic rules of Indonesian traffic that give way to vehicles from the left, while the signal intersections are controlled by traffic light.

\subsection{Intersection Type}

The intersection/ Intersection Type (IT) type is determined by the number of intersection arms and the number of lanes on the major and minor roads in the intersection with a three-digit code as shown in table 1 . 
Table 1. Code Intersection Type (IT)

\begin{tabular}{|c|c|c|c|}
\hline $\begin{array}{c}\text { Code } \\
\text { IT }\end{array}$ & $\begin{array}{c}\text { Number of arms } \\
\text { intersection }\end{array}$ & $\begin{array}{c}\text { Number Of } \\
\text { Minor Road } \\
\text { Lanes }\end{array}$ & $\begin{array}{c}\text { Number of } \\
\text { Major Road } \\
\text { Lines }\end{array}$ \\
\hline 322 & 3 & 2 & 2 \\
\hline 324 & 3 & 2 & 4 \\
\hline 342 & 3 & 4 & 2 \\
\hline 422 & 4 & 2 & 2 \\
\hline 424 & 4 & 2 & 4 \\
\hline
\end{tabular}

Source: MKJI 1997

\subsection{Non-signal Intersection Performance}

Intersection performance is a condition at the intersection that must be sought to determine the level of achievement of the intersection. The parameter that must be sought to find out the intersection performance is the ratio between capacity (Capacity/ C) and existing traffic flow (Q). From the ratio of capacity, current will be obtained the number of degrees of saturation (Degree of saturation/ DS). With the value of degree of saturation (DS) and capacity value (C), the level of performance of each approach can be calculated as well as the overall level of intersection performance. The level of performance measured in the Indonesian Road Capacity Manual (MKJI 1997) is the delay (Delays/ D) and the chance of queuing.

\subsubsection{Traffic Flow (Q)}

The traffic flow used in the intersection capacity analysis is used the most congested traffic flow per hour from the overall movement of the vehicle. The total vehicle flow is the vehicle per hour for each movement calculated by\% (prosent) conversion vehicles, namely passenger car ekivalents (pce).

$\mathrm{Q}_{\mathrm{PCU}}=$ Qkeng $\mathrm{x} \mathrm{Kpcu}$

Information:

$\mathrm{Q}_{\mathrm{PCU}}=$ total current at the intersection (pcu / hour)

$\mathrm{Q}_{\mathrm{keng}}=$ current there are each intersection (pcu / hour)

$$
\mathrm{K}_{\mathrm{PCU}}=\text { factor } \mathrm{pcu}
$$

The passenger car unit (pcu) factor for various types of vehicles can be calculated using the formula

$\mathrm{K}_{\text {smp }}=(\mathrm{LV} \% \mathrm{x}$ pce $\mathrm{LV}+\mathrm{HV} \% \mathrm{x}$ peeHV $\mathrm{x} \mathrm{MC} \% \mathrm{x}$ pceMC) / 100

\subsubsection{Non-signal Intersection Capacity}

MKJI (1997) defines that capacity is the maximum maintained (fixed) traffic flow on a part of the road under certain conditions stated in vehicles/ hours or junior / hour.

The total capacity of an intersection can be expressed as a result of multiplication between basic capacity $(\mathrm{Co})$ and adjustment factors (F). The formulation of intersection capacity according to MKJI 1997 is written as follows:

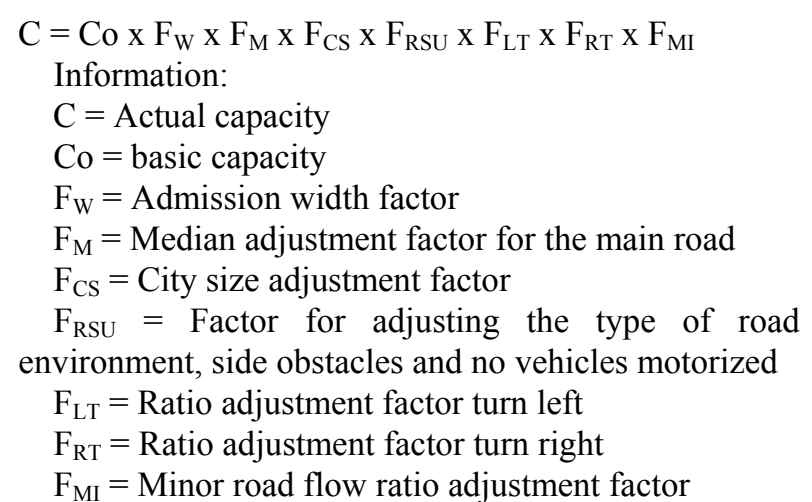

\subsubsection{Degree of Saturation}

Degree of saturation (DS) is the comparison between traffic volume and road capacity, used as the main factor in determining the level of performance of intersections and road segments. The DS value indicates whether the road segment has a capacity problem or not.

The basic equation to determine the value of the degree of saturation as follows:

$$
\begin{aligned}
& \mathrm{DS}=\mathrm{Q}_{\mathrm{PCU}} / \mathrm{C} \\
& \text { Information: } \\
& \text { DS = Degree of saturation } \\
& \mathrm{C}=\text { Capacity (pcu / hour) }
\end{aligned}
$$

\subsubsection{Delay (D)}

Cross traffic delay is the total time the average obstacle experienced by a vehicle when passing a side.

1. Average traffic delay for all intersections $\left(\mathrm{DT}_{\mathrm{i}}\right)$

For DS 60.6 :

$\mathrm{DT}_{\mathrm{i}}=2+(8,2078 \times \mathrm{DS})-[(1-\mathrm{DS}) \times 2]$

For DS $>0.6$

$$
\mathrm{DT}_{\mathrm{i}}=((1.0504 /[0.2742-(0.2042 \times \mathrm{DS})]))-[(1-\mathrm{DS})
$$

$$
\mathrm{x} 1,8]
$$

2. Average traffic delay for major roads $\left(\mathrm{DT}_{\mathrm{MA}}\right)$

For DS 60.6 :

$$
\begin{aligned}
& \mathrm{DT}_{\mathrm{MA}}=1.8+(5,8234 \times \mathrm{DS})-[(1-\mathrm{DS}) \times 1,8] \\
& \text { For DS>0.6 } \\
& \mathrm{DT}_{\mathrm{MA}}=((1.0504 /[0.346-(0.246 \times \mathrm{DS})]))-[(1-\mathrm{DS})
\end{aligned}
$$$$
\mathrm{x} 1,8]
$$

3. Minor road average traffic delay $\left(\mathrm{DT}_{\mathrm{MI}}\right)$

$$
\mathrm{DT}_{\mathrm{MI}}=\left[\left(\mathrm{Q}_{\mathrm{SMP}} \times \mathrm{DT}_{\mathrm{i}}\right)-\left(\mathrm{Q}_{\mathrm{MA}} \times \mathrm{DT}_{\mathrm{MA}}\right)\right] / \mathrm{Q}_{\mathrm{MI}}
$$

Information:

$\mathrm{Q}_{\mathrm{PCU}}=$ Actual total flow (pcu / hour)

$\mathrm{Q}_{\mathrm{MA}}=$ Number of vehicles entering at the intersection major road (pcu / hour)

$\mathrm{Q}_{\mathrm{MI}}=$ Number of vehicles entering at the intersection minor road (junior / hour)

4. Geometric delay intersection (DG)

DG is calculated using the equation:

For DS $<1.0$ :

$\mathrm{DG}=(1-\mathrm{DS}) \times(\operatorname{Pr} \times 6+(1-\mathrm{Pr}) \times 3)+\mathrm{DS} \times 4$

For DS> 1.0

$\mathrm{DG}=4 \mathrm{sec} / \mathrm{pcu}$ 


\subsubsection{Queue Opportunities (QP\%)}

The limit of the QP\% queue probability value is determined by the empirical relationship between the probability of QP queue \% and the degree of saturation of the DS. Opportunities for queuing with upper and lower limits can be obtained using the following formula below

Upper limit :

$\mathrm{QP}_{\mathrm{a}}=(47.71 \times \mathrm{DS})-(24.68 \times \mathrm{DS} 2)+(56.47 \times \mathrm{DS} 2)$

Lower limit :

$\mathrm{QP}_{\mathrm{b}}=(9.02 \times \mathrm{DS})+(20.66 \times \mathrm{DS} 2)+(10.49+\mathrm{DS} 2)$

\subsection{Level of Road Services}

MKJI 1997 explains that the level of road service can be calculated based on the scope of the Q / C road section, as shown in Table 2.

Table 2. Relationship capacity with level

\begin{tabular}{|c|c|l|}
\hline $\begin{array}{c}\text { Service } \\
\text { Level }\end{array}$ & Q/C & \multicolumn{1}{|c|}{ Characteristics } \\
\hline A & $0,00-0,19$ & Free flow, low volume and high speed, the driver can choose the path he wants \\
\hline B & $0,20-0,44$ & $\begin{array}{l}\text { The current is stable, the speed is slightly limited by traffic, the volume of service used to design lines } \\
\text { outside the city }\end{array}$ \\
\hline C & $0,45-0,74$ & Stable current, speed controlled by traffic, volume of service used for urban roads \\
\hline D & $0,75-0,84$ & Approaching an unstable, low speed current \\
\hline E & $0,85-1,00$ & Unstable current, easy speed and different volume capacity \\
\hline F & $>1,00$ & Obstructed currents, low speed volumes above capacity and many stops \\
\hline
\end{tabular}

Source: Warpani Swardjoko, Rekayasa Lalu Lintas, Brata Karya Aksara, Jakarta 1985

\section{Research Methodology}

The flow of thought in the research methodology can be described as in Figure 1: 


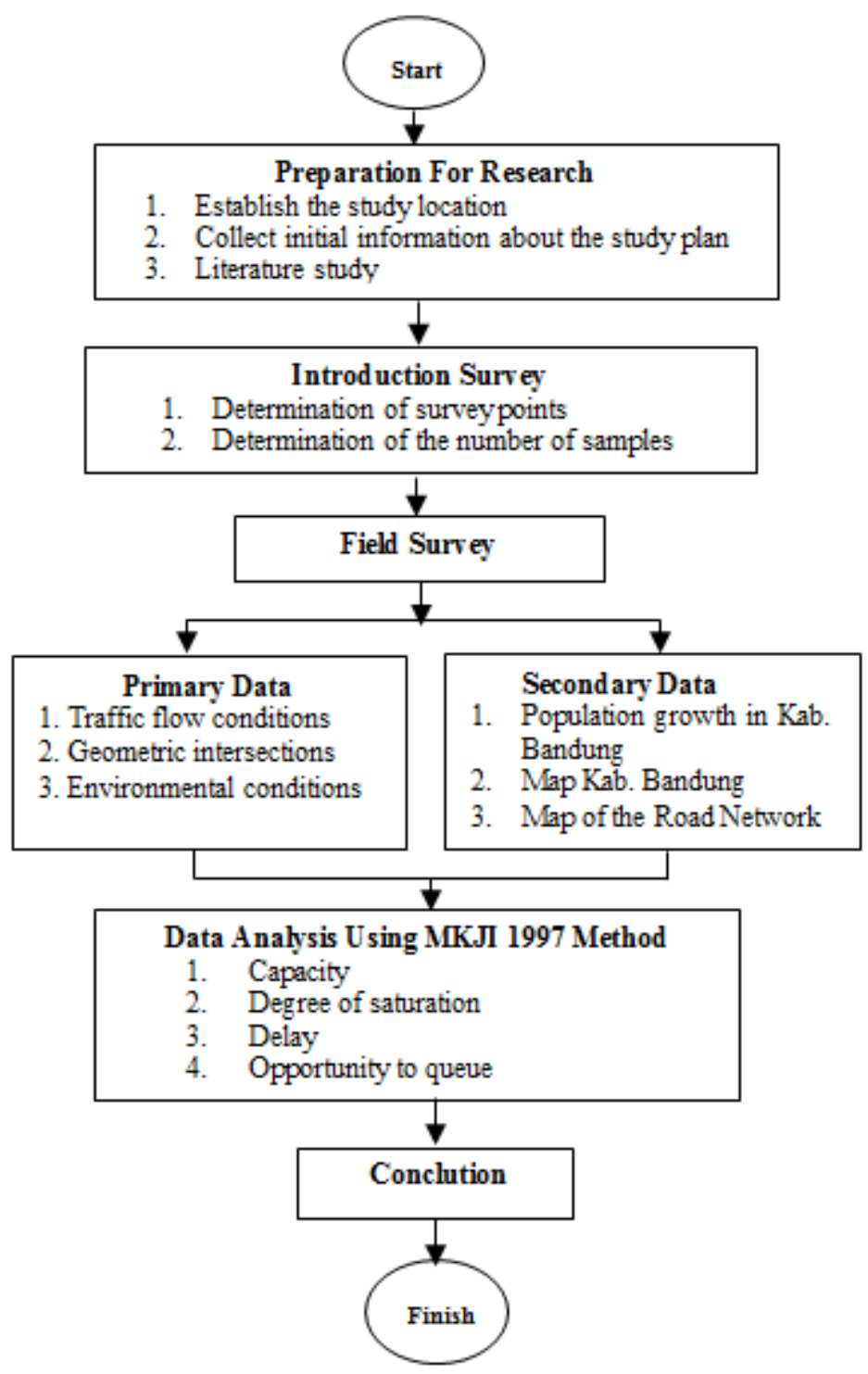

Figure 1. Research Flow Chart

\subsection{Research Sites}

This research was carried out at the Telecommunication Street unsignalized intersection - on Jalan Terusan Buah Batu, Bandung Regency, West Java Province - Indonesia.

\section{Data Processing and Analysis}

\subsection{Data Collection}

Data collection at the intersection that will be analyzed is carried out for 3 days with a one-hour time period in the morning, noon and afternoon. Data retrieval was carried out directly in the field on each intersection arm. From each arm observed all data for morning, noon and afternoon were taken for one hour. Data collection at the Telekomunikasi Road intersection - Terusan Buah Batu Road on Monday 14th January 2019 period morning at
06.20 - 07.20 WIB, noon 11:50 - 12:50 WIB, afternoon at 15:20 - 1620 WIB; Wednesday 16th January 2019 morning period 06:20 - 07.20 WIB, noon 11:50 - 12:50 WIB, afternoon at 15:20 - $1620 \mathrm{WIB}$; and Saturday 19th January 2019 morning period 06:20 - 07.20 WIB, noon 11:50 - 12, 50 WIB, afternoon at 15:20 - 1620 WIB.

\subsection{Data Processing}

\subsubsection{Intersection Data}

Telekomunikasi Road Intersection - Terusan Buah Batu Road is a non-signal three-arm intersection located on the crossing of the Terusan Buah Batu and serves as a major/ major road at the intersection. The condition of each road section consists of two directions and two lanes without borders (median). On the main road and minor roads, there are sidewalks on both sides of the road.

Data on Telekomunikasi Road intersection - Terusan Buah Batu Road can be seen in Figure 2. 


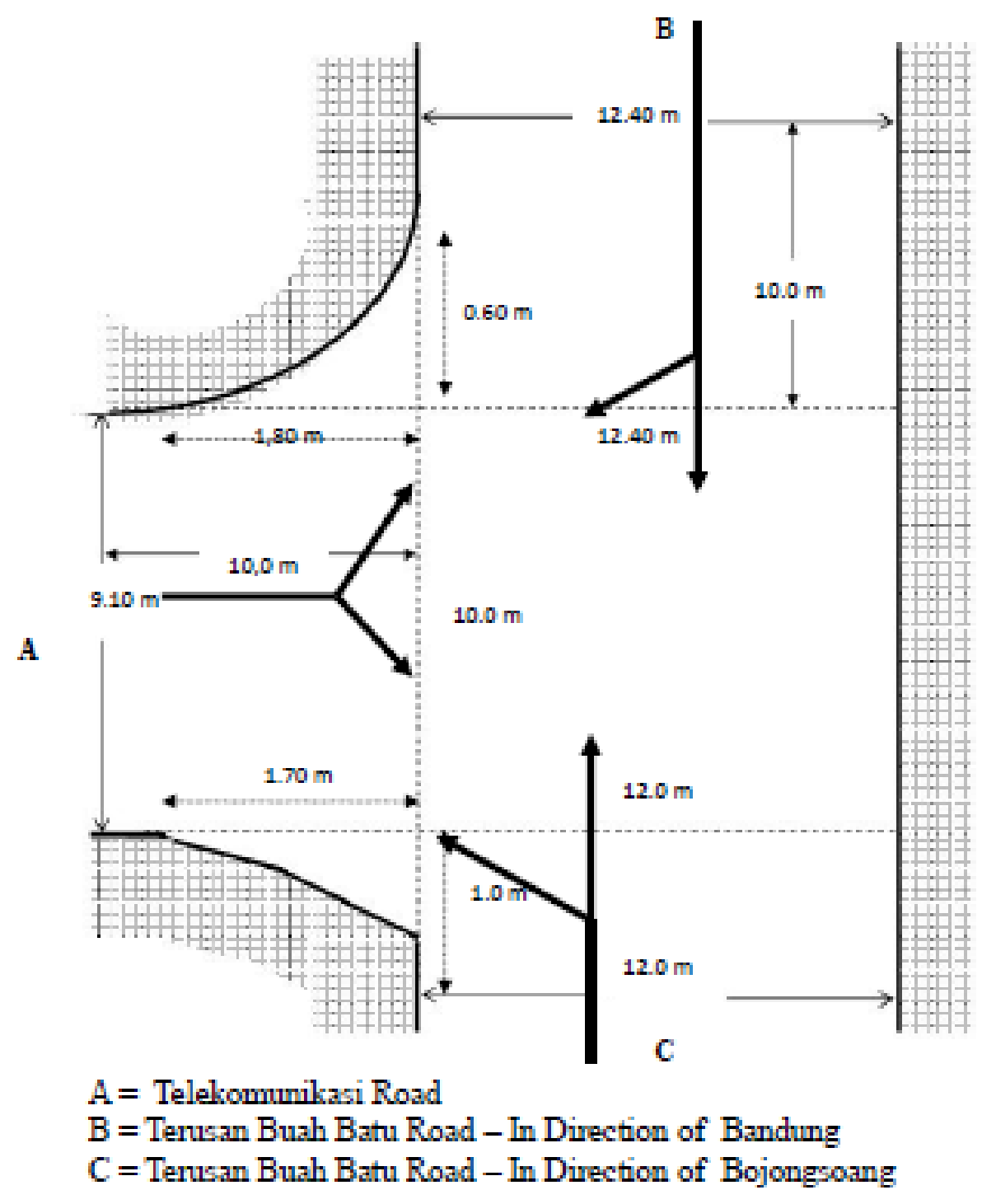

Figure 2. Telekomunikasi Road Intersection - Terusan Buah Batu Road

4.2.2. Traffic Volume

Vehicle volume observed can be seen in the table 3 . 
Table 3. Vehicle Volume Observation

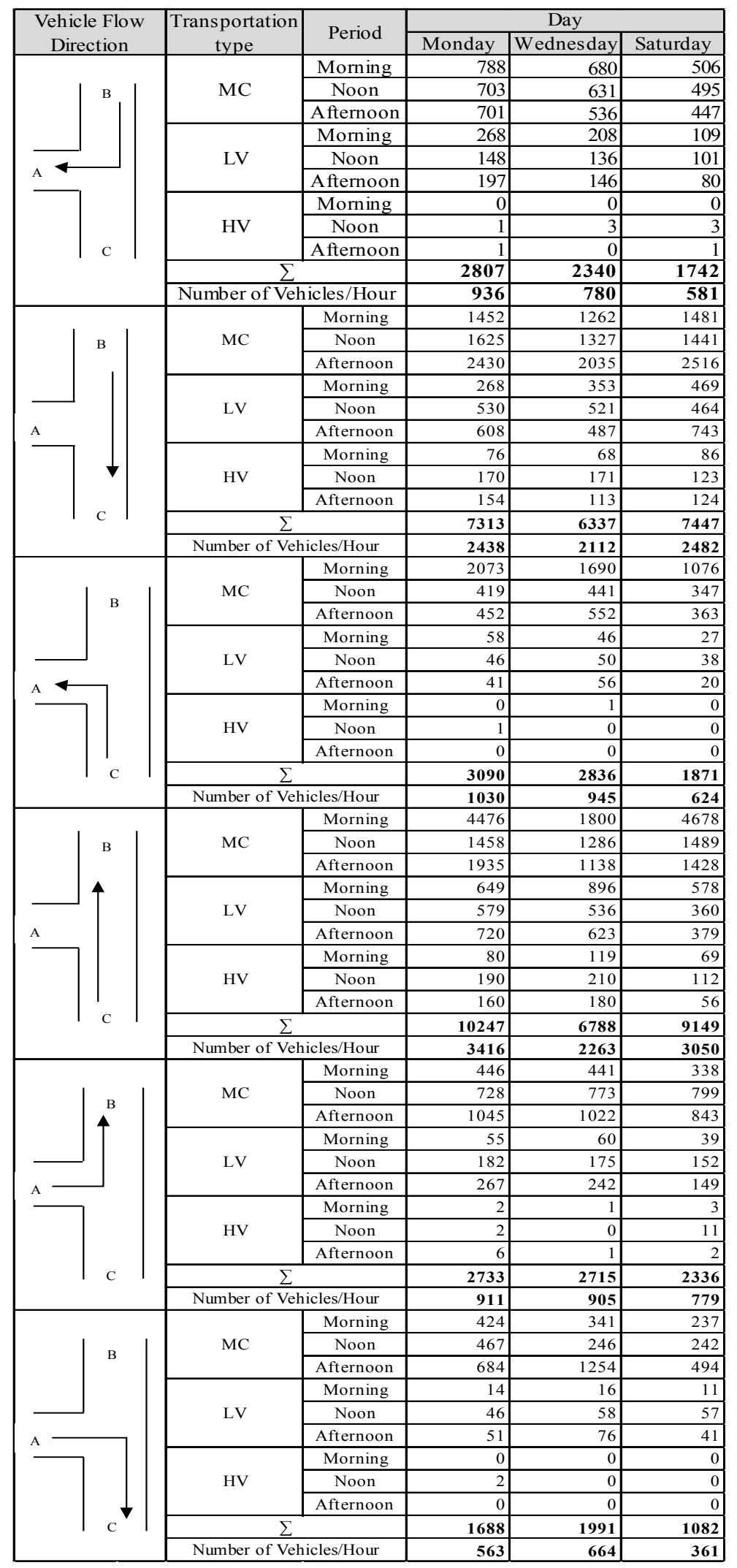




\section{Analysis and Discussion}

\subsection{Performance of Non-signal Intersection Analysis}

Non-signalized intersection performance analysis is done by computerization, where the intersection performance analyzed includes capacity (C), degree of saturation (DS), delay (D) and queuing opportunity (DS) based on the Indonesian Road Capacity Manual (MKJI) 1997.

The flow chart (Flow chart) which will be a reference procedure for calculating and analyzing the data as follows:

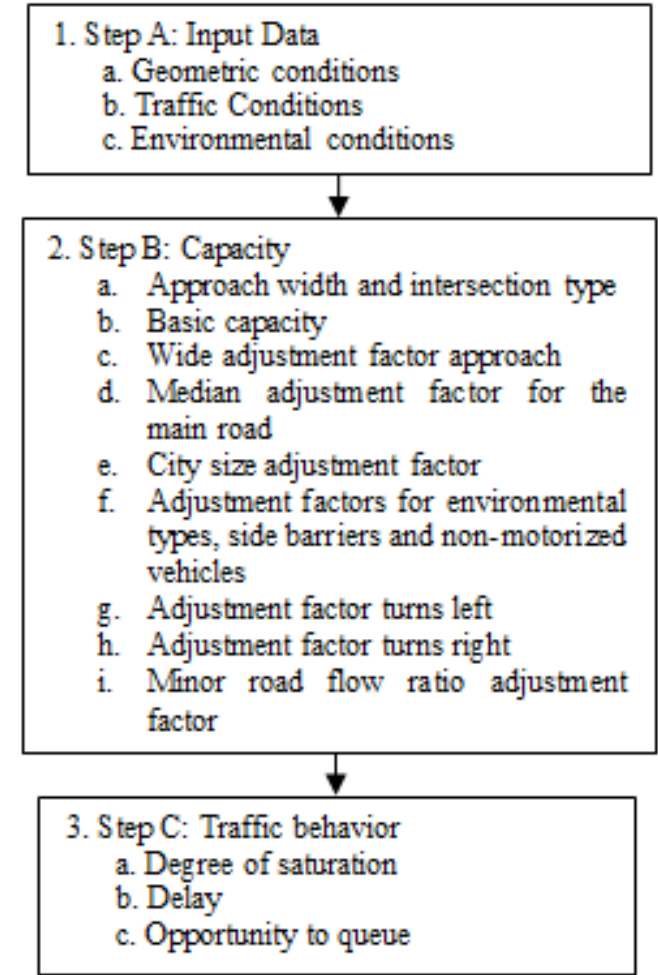

Figure 3. Flow Chart of Operational Analysis Procedures

\subsection{Calculation of Survey Data}

\section{a. Intersection Capacity $\mathbf{C}$}

1) The average width of the intersection approach $\mathrm{W}_{\mathrm{AC}}=\left(\mathrm{W}_{\mathrm{A}}+\mathrm{W}_{\mathrm{C}}\right) / 2=(9.1+0) / 2=4.55 \mathrm{~m}$

$\mathrm{W}_{\mathrm{BD}}=\left(\mathrm{W}_{\mathrm{B}}+\mathrm{W}_{\mathrm{D}}\right) / 2=(12.40+12.0) / 2=12.20 \mathrm{~m}$

$\mathrm{W}=\left(\mathrm{W}_{\mathrm{A}}+\mathrm{W}_{\mathrm{B}}+\mathrm{W}_{\mathrm{C}}+\mathrm{W}_{\mathrm{D}}\right) /$ Number of intersection $\operatorname{arms}=(9.1+12.40+12.0) / 3=11.20 \mathrm{~m}$

\section{2) Intersection type}

Code Type Intersection and figure 2 Geometric Plan of Non-Signal Intersection Three Arms of Telekomunikasi Road -Terusan Buah Batu Road then this intersection includes type 324

3) Basic capacity

The basic capacity is adjusted to the three arm intersection type (code 324), the basic value of $\mathrm{Co}=3200$

4) Approach width adjustment factor $\left(\mathrm{F}_{\mathrm{W}}\right)$

The $\mathrm{F}_{\mathrm{W}}$ value is obtained from the ratio of the average approach width to the intersection type 324 then:

$\mathrm{F}_{\mathrm{W}}=0.62+0.0646 \times \mathrm{W}_{\mathrm{I}}=1.343$

5) The median adjustment factor for the $F_{M}$ main road Median narrow road $(\ll 3 \mathrm{~m})$. then the $F_{M}$ value $=1.05$.

6) Factors adjusting the size of the city of $F_{C S}$

The size of Bandung Regency with a population of 3,534,114 inhabitants (data from the Central Bureau of Statistics of Bandung Regency in 2018), so that it belongs to a large category, then the $\mathrm{F}_{\mathrm{CS}}$ value $=1.00$

7) Factors adjusting the type of road environment, side barriers and $\mathrm{F}_{\mathrm{RSU}}$ non-motorized vehicles

Factors adjusting the type of road environment, side barriers and non-motorized vehicles assuming this intersection is a commercial environmental type (RE) with low side resistance $(\mathrm{SF})$, and the ratio of non-motorized vehicles $\left(\mathrm{p}_{\mathrm{UM}}\right)$ is $0.00, \mathrm{~F}_{\mathrm{RSU}}=$ taken 0.95

8) Adjustment factor for turning left $\mathrm{F}_{\mathrm{LT}}$

$\mathrm{P}_{\mathrm{LT}}=\left(\mathrm{Q}_{\mathrm{LT}} / \mathrm{Q}_{\mathrm{TOT}}\right)$

$\mathrm{Q}_{\mathrm{LT}}$ value $=$ vehicle volume turn left from the main road and minor road

$\mathrm{Q}_{\mathrm{TOT}}$ value $=$ overall vehicle volume from the main road and minor road

$$
\begin{aligned}
& \mathrm{P}_{\mathrm{LT}}=(1385,3 / 6356.9)=0,21789 \\
& \mathrm{~F}_{\mathrm{LT}}=0,84+1,61 \times \mathrm{P}_{\mathrm{LT}}=1,191
\end{aligned}
$$

9) Adjustment factor turns right FRT

$$
\begin{aligned}
& \mathrm{P}_{\mathrm{RT}}=\left(\mathrm{Q}_{\mathrm{RT}} / \mathrm{Q}_{\mathrm{TOT}}\right) \\
& \mathrm{P}_{\mathrm{RT}}=(888 / 6356.9)=0.13969 \\
& \mathrm{~F}_{\mathrm{RT}}=1.09-0.922 \mathrm{PRT}=0.961
\end{aligned}
$$

10) $\mathrm{F}_{\mathrm{MI}}$ minor road flow ratio adjustment factor $\mathrm{P}_{\mathrm{MI}}=(516,6 / 6356.9)=0.08127$

$\mathrm{F}_{\mathrm{RT}}=16.6 \times \mathrm{P}_{\mathrm{MI} 2}-33.3 \times \mathrm{P}_{\mathrm{MI} 3}+25.3 \times \mathrm{P}_{\mathrm{MI} 2}-8.6 \times \mathrm{P}_{\mathrm{MI}}$ $+1.95=1,510$

11) Capacity value

$\mathrm{C}=\mathrm{Co} \times \mathrm{F}_{\mathrm{W}} \times \mathrm{F}_{\mathrm{M}} \times \mathrm{F}_{\mathrm{CS}} \times \mathrm{F}_{\mathrm{RSU}} \times \mathrm{F}_{\mathrm{LT}} \times \mathrm{F}_{\mathrm{RT}} \times \mathrm{F}_{\mathrm{MI}}$

$\mathrm{C}=3200 \times 1,343 \times 1.05 \times 1.0 \times 0.95 \times 1,191 \times 0.961 \times$ $1,510=7400 \mathrm{pcu} /$ hour

\section{b. Work Level}
1) Degree of Saturation of DS
$\mathrm{DS}=\mathrm{Q}_{\mathrm{TOT}} / \mathrm{C}$
$\mathrm{DS}=6356,9 / 7400=0,859$ 
Table 4. Results of Capacity Recapitulation and Intersection Performance Levels

\begin{tabular}{|c|c|c|c|c|c|c|c|c|c|}
\hline Day & Time Interval & $\begin{array}{c}\mathrm{C} \\
(\mathrm{pcu} / \mathrm{hour})\end{array}$ & $\mathrm{DS}$ & $\mathrm{DT}_{\mathrm{I}}$ & $\mathrm{DT}_{\mathrm{MA}}$ & $\mathrm{DT}_{\mathrm{MI}}$ & $\begin{array}{c}\mathrm{DG} \\
(\mathrm{sec} / \mathrm{cu})\end{array}$ & $\begin{array}{c}\mathrm{D} \\
(\mathrm{sec} / \mathrm{pcu})\end{array}$ & $\mathrm{QP} \%$ \\
\hline \multirow{4}{*}{ Monday } & $06 . .20-7.20$ & 7400 & $\mathbf{0 , 8 6}$ & 10,38 & 7,55 & 42,42 & 4,016 & 14,39 & $34,22 \%-64,44 \%$ \\
\cline { 2 - 11 } & $11.50-12.50$ & 6953 & 0,68 & 7,14 & 5,27 & 15,88 & 4,042 & 11,19 & $26,52 \%-46,87 \%$ \\
\cline { 2 - 11 } & $15.20-16.20$ & 7496 & 0,79 & 8,93 & 6,55 & 18,41 & 4,020 & 12,95 & $31,15 \%-57,57 \%$ \\
\hline \multirow{4}{*}{ Wednesday } & $06.20-7.20$ & 7398 & 0,67 & 7,01 & 5,17 & 24,51 & 4,103 & 11,11 & $26,12 \%-45,93 \%$ \\
\cline { 2 - 11 } & $11.50-12.50$ & 7324 & 0,60 & 6,24 & 4,60 & 13,29 & 4,079 & 10,32 & $23,80 \%-40,34 \%$ \\
\cline { 2 - 10 } & $15.20-16.20$ & $\mathbf{9 3 2 6}$ & 0,56 & 5,75 & 4,30 & 9,55 & 4,166 & 9,92 & $22,45 \%-36,98 \%$ \\
\hline \multirow{3}{*}{ Saturday } & $06.20-7.20$ & 7204 & $\mathbf{0 , 7 8}$ & 8,75 & 6,42 & 42,12 & 3,942 & 12,69 & $30,72 \%-56,59 \%$ \\
\cline { 2 - 10 } & $11.50-12.50$ & 7869 & 0,51 & 5,19 & 3,88 & 10,11 & 4,068 & 9,26 & $20,68 \%-32,50 \%$ \\
\cline { 2 - 10 } & $15.20-16.20$ & 7266 & 0,65 & 6,75 & 4,97 & 14,62 & 3,983 & 10,73 & $25,36 \%-44,10 \%$ \\
\hline
\end{tabular}

2) Delays

a) Total delay $\left(\mathrm{D}_{\text {Tот }}\right)$, which is the average traffic delay for all motorized vehicles entering the intersection

For DS $>0.6$

$\mathrm{DT}_{\mathrm{i}}=((1,0504 /[0,2742-(0,2042 \times \mathrm{DS})]))-[(1-\mathrm{DS}) \mathrm{x}$ 1,8

$\mathrm{DT}_{\mathrm{i}}=((1,0504 /[0,2742-(0,2042 \times 0,859)]))-$ $[(1-0,859) \times 1,8=10,380 \mathrm{sec} /$ hour

b) Average traffic delay for the main road ( $\left.\mathrm{D}_{\text {TMA }}\right)$

For DS $>0,6$

$1,8]$

$\mathrm{DT}_{\mathrm{MA}}=((1,0504 /[0,346-(0,246 \times D S)]))-[(1-D S) \times$

$\mathrm{DT}_{\mathrm{MA}}=\left(\left(\begin{array}{ccc}1,0504 /[0,346-(0,246 & \mathrm{x} & 0,859)]))\end{array}\right)\right.$

$[(1-0,859) \times 1,8]=7,55 \mathrm{sec} /$ hour

c) Minor road / intersection $\left(\mathrm{DT}_{\mathrm{MI}}\right)$ average traffic delay

$\mathrm{DT}_{\mathrm{MI}}=\left[\left(\mathrm{Q}_{\mathrm{TOT}} \times \mathrm{DT}_{\mathrm{i}}\right)-\left(\mathrm{Q}_{\mathrm{MA}} \times \mathrm{D}_{\mathrm{TMA}}\right)\right] / \mathrm{Q}_{\mathrm{MI}}$

$\mathrm{DT}_{\mathrm{MI}}=[(6356.9 \times 10,380)-(5,840.3 \times 7,546)] /$

$516,6=42,42 \mathrm{sec} /$ hour

d) Geometric delay intersection (DG)

DG is calculated using the equation:

For DS $<1.0$ :

$\mathrm{DG}=(1-\mathrm{DS}) \times(\operatorname{Pr} \times 6+(1-\operatorname{Pr}) \times 3)+\mathrm{DS} \times 4$

$\mathrm{DG}=(1-0,859) \times(0.37205 \times 6+(1-0.37205) \times 3)$

$+0.859 \times 4=4.02 \mathrm{sec} /$ hour

3) $\mathrm{QP} \%$ Queue Opportunity

a) Opportunity to queue 1 (Bottom)

$\mathrm{QP}_{\mathrm{b}}=(9.02 \times \mathrm{DS})+(20.66 \times \mathrm{DS} 2)+(10.49+\mathrm{DS} 2)$

$\mathrm{QP}_{\mathrm{b}}=(9.02 \times 0.859)+(20.66 \times 0.8592)+(10.49+$ $0.8592)=34.22 \%$

b) Opportunity to queue II (Top)

$\mathrm{QP}_{\mathrm{a}}=(47.71 \times \mathrm{DS})-(24.68 \times \mathrm{DS} 2)+(56.47 \times \mathrm{DS} 2)$

$\mathrm{QP}_{\mathrm{a}}=(47.71 \times 0.86)-(24.68 \times 0.862)+(56.47 \times$

$0.862)=64.44 \%$

By using the same method, the recapitulation and deviation performance levels are obtained as shown in table 4 .

\subsection{Discussion}

The results of the calculation can be seen that at the intersection of Telokomunikasi Road - Terusan Buah Batu Road, it is not feasible to accommodate traffic flow as a consideration in controlling and managing future traffic. The maximum value of the maximum capacity at the intersection is $9326 \mathrm{pcu} /$ hour, occurring on Wednesday 16th January 2019 at $15.20-16.20$, already exceeding the basic capacity $(\mathrm{Co}=3200 \mathrm{pcu} /$ hour $)$. This will continue to increase in line with population growth with the increasing number of vehicles

While based on the calculation of degree of saturation (DS) obtained value of 0.859 occurred on Monday 14th January 2019 at $06.20-207.20$, which states that for the service level is in class E $(0.85-1.00)$, i.e. the traffic flow is unstable; the vehicle is solid; the traffic is stagnant and the intersection volume is higher than its capacity. This situation results in losses that must be borne by the driver, including increased operational costs, delayed travel time and also impact on comfort,

\section{Conclusions}

Based on the formulation of the problem and the results of the calculation of non-signal intersections on Telekomunikasi Road - Terusan Buah Batu Road in Bandung Regency by using the 1997 Indonesian Road Capacity Manual (MKJI) Guidelines, the following conclusions can be obtained:

1. Based on the results of the analysis of the level of intersection performance obtained as follows:

a. On Monday which shows the highest DS value (Degree of saturation) is at $06.20-7.20$, which is equal to 0.86 , and the value for the service level is in class $\mathrm{E}(0.85-1.00)$, namely the flow of traffic unstable, solid vehicles, stagnant traffic and intersection volume higher than capacity.

b. On Wednesday which shows the highest DS value (degree of saturation) is at $06.20-7.20$, which is equal to 0.67 , and the value for the service level is 
in class $\mathrm{C}(0.45-0.74)$, namely traffic flow stable, speed is controlled by traffic.

c. On Saturday which shows the highest DS value (degree of saturation) is at $06.20-7.20$, which is equal to 0.78 , and the value for the service level is in class $\mathrm{D}(0.75-0.84)$, namely traffic flow unstable, low speed.

d. On Wednesday at 15:20 - 16:20, the maximum capacity value of $9326 \mathrm{pcu} /$ hour exceeded the basic 324 junction capacity $(\mathrm{Co}=3200 \mathrm{pcu} /$ hour).

2. From the above data volume results in a decrease in the level of intersection performance due to the delay experienced by each vehicle and the Telekomunikasi Road intersection - Terusan Buah Batu Road is not feasible to accommodate traffic flows.

The results of this study are suggested as follows:

1. A better traffic control system is needed at intersections, such as making stop lines, road markers as vehicle lane separators and warning signs, danger signs or by installing traffic signal lights. This is deemed necessary to be carried out immediately by the parties concerned in order to improve service and anticipate congestion at the intersection

2. It is necessary to review the geometric compatibility of intersections based on current traffic conditions and predictions for the coming year

3. The government is expected to pay more attention to unsignalized intersections that have been troubled by deploying officers related to traffic control, namely traffic police so that during rush hour the traffic flow remains smooth

\section{REFERENCES}

[1] BPS, 2016, Kabupaten Bandung Dalam Angka, Badan Pusat Statistik, Kabupaten Bandung

[2] Juniardi, "Analisis Arus Lalu Lintas Di Simpang Tak Bersinyal (studi Kasus: Simpang Timoho dan Simpang Tanjung di Kota Yogyakarta)", Tesis, Program Pascasarjana Universitas Diponogoro Semarang, 2006, p. $8-13$

[3] MKJI, 1997, Manual Kapasitas Jalan Indonesia (MKJI), Departemen Pekerjaan Umum, Jakarta

[4] Suwardjoko Warpani Ir, Jakarta 1985, "Rekayasa Lalu Lintas", Bhrata KaryaAksara

[5] Suwardjoko Warpani Ir, Bandung 2002, "Pengelolaan Lalu Lintas dan AngkutanJalan", Institut Teknologi Bandung

[6] Jabarullah, N.H., Shabbir, M.S., Abbas, M., Siddiqi, A.F. \& Berti, S. (2019) Using random inquiry optimization method for provision of heat and cooling demand in hub systems for smart buildings, Sustainable Cities and Society, 47, 101475 .
[7] Sisay, T., Verma, D., Berhane, N., \& Tsegaw, M. (2018). Vaccine Development Strategies, Progresses and Challenges for Human Immunodeficiency Virus (HIV): A Review. The International Journal of Biotechnology, 7(1), 8-16. 